\title{
Role of Herpesvirus as a Cause of Mononucleosis-Like and Febrile Syndromes in Cuba, 2006-2009
}

\author{
Consuelo Correa MD MS, Pedro A. Martínez MD MS, Lissette Pérez MS PhD, Alina Álvarez, Yoan Alemán MS, \\ Yudira Soto MS, Vivian Kourí MD PhD
}

\begin{abstract}
INTRODUCTION Herpesvirus infections are prevalent worldwide, but most run their course asymptomatically. Clinical presentations in symptomatic cases vary widely and include febrile and mononucleosis-like syndromes. In immunocompromised patients, herpetic infection can be lethal and routine laboratory tests are of little use. Use of novel techniques may provide important improvements in diagnosis and treatment of these patients.

OBJECTIVE Investigate association between different herpesviruses and the etiology of mononucleosis and febrile syndromes in Cuban immunocompetent and immunocompromised patients.

METHODS The study used multiplex nested polymerase chain reaction, enabling simultaneous detection of six herpesviruses-cytomegalovirus, herpes simplex (1 and 2), Epstein-Barr, varicella-zoster and human herpesvirus 6-to study 1157 samples (770 urine and 387 serum samples) from 1140 patients with mononucleosis-like syndrome or febrile syndrome, classified according to history of immunosuppressive disease. Samples were analyzed at the Laboratory for Sexually Transmitted Diseases (Virology) of the Pedro Kourí Tropical Medicine Institute from January 2006 through December 2009. SPSS statistical package was used and incidence rates calculated.
\end{abstract}

\section{INTRODUCTION}

Herpesvirus infections are very frequent worldwide, with population prevalences reaching $>90 \%$ in developing countries and $>60 \%$ in developed countries. The most important biologic characteristic of these viruses is their capacity to establish lifelong latency after primary infection, with variable reactivation periods.[1]

There are eight known human herpesviruses: herpes simplex viruses 1 and 2 (HSV); varicella-zoster virus (VZV); cytomegalovirus (CMV); Epstein-Barr (EBV); and human herpesviruses 6, 7 and 8 (HHV-6, HHV-7 and HHV-8). Most herpetic infections, primary as well as reactivations or reinfections, run their course asymptomatically.[2-4] The clinical spectrum varies widely, from acute, benign or self-limited diseases to more severe forms, particularly in immunosuppressed patients in which infection can lead to major complications or death.[2-5] Of particular importance among these are febrile syndrome (FS) and mononucleosis-like syndrome (MLS), organ rejection accompanied by fever in transplant recipients, encephalitis, EBV-associated lymphomas, and congenital CMV disease. Herpesviruses are hence considered typically opportunistic pathogens.[6,7]

The situation is complicated when clinical manifestations are nonspecific, since different herpesviruses cause similar clinical presentations, making it difficult and laborious to reach a correct diagnosis.[8,9] Serological tests have limited value, since they do not always permit diagnosis of active infection, especially in immunocompromised patients, in whom low levels of IgM are observed up to one or two years after infection.[10,11] This is when molecular methods, such as polymerase chain reaction $(\mathrm{PCR})$, become an alternative for rapid and highly sensitive differential diagnosis of active herpes infection.[10,11]
RESULTS Of samples studied, $20.1 \%$ were positive for some herpesvirus. Higher risk of developing active herpesvirus infections was detected in samples from immunocompromised patients with febrile syndrome compared to those of immunocompetent ones (OR 2.02, Cl $1.20-3.42, p=0.007)$. Cytomegalovirus was the most frequently found herpesvirus in both mononucleosis-like syndrome $(60.4 \%)$ and febrile syndrome $(63.6 \%)$ and in both children $(69.2 \%)$ and adults $(55.2 \%)$, followed by Epstein-Barr virus. Cytomegalovirus was detected in $68.9 \%$ of positive urine samples and in just $47.2 \%$ of serum samples.

CONCLUSIONS This is the first Cuban study demonstrating the pathogenic role of herpesviruses, particularly cytomegalovirus, in patients with febrile or mononucleosis-like syndrome, in both immunocompetent and immunocompromised patients. Results highlight the importance of including molecular diagnosis of the herpesvirus family in investigating mononucleosis and febrile syndromes of unknown etiology and demonstrate that etiologic diagnosis would not have been feasible in many cases without the use of this diagnostic tool.

KEYWORDS Herpesvirus, HHV-1, HHV-2, HHV-6, varicella zoster, CMV, EBV, PCR, mononucleosis, fever, immunosuppression, Cuba
Because of the high frequency worldwide of patients seeking medical attention with mononucleosis and febrile syndromes of unknown etiology[12] and absence of previous reports in Cuba on the etiology of these syndromes, we carried out this first study in Cuba of association between various herpesviruses and etiology of FS and MLS in immunocompetent and immunocompromised patients. This paper describes results from analysis of samples collected nationwide from such patients in whom herpetic disease was suspected.

\section{METHODS}

The Laboratory for Sexually Transmitted Diseases (Virology) (LSTD) of the Pedro Kourí Tropical Medicine Institute (IPK) is the only center in Cuba where samples are analyzed from patients with different clinical presentations and suspicion of herpetic etiology. These include MLS and acute or prolonged FS in immunocompetent patients or in patients with prior immunosuppressive diseases or conditions (such as cancer, HIVIAIDS, or organ transplant).

Study population Samples (1157) from 1140 patients were studied; 770 (66.5\%) were urine samples and 387 (33.5\%) serum. These were received at the IPK Laboratory for Sexually Transmitted Diseases (Virology) from January 2006 through December 2009. Samples came from patients evidencing MLS or FS and in whom active herpesvirus infection was suspected according to clinical history. Samples were divided into six groups according to clinical classification, as shown in Table 1. No samples with MLS were received from transplanted or other patients with immunosuppressive diseases. 
Table 1: Serum and urine samples studied, by clinical group and life stage

\begin{tabular}{|l|l|r|r|r|}
\hline Group & Clinical characteristics & Children & Adults & \multicolumn{1}{|c|}{ Total } \\
\hline 1 & MLS, immunocompetent & 249 & 65 & 314 \\
\hline 2 & FS, immunocompetent & 104 & 45 & 149 \\
\hline 3 & FS, transplanted & 46 & 49 & 95 \\
\hline 4 & MLS, HIV+ & 0 & 215 & 215 \\
\hline 5 & FS, HIV+ & 17 & 205 & 222 \\
\hline 6 & $\begin{array}{l}\text { FS, other } \\
\text { immunosuppressive }\end{array}$ & 88 & 74 & 162 \\
\hline & disease & 504 & 653 & 1157 \\
\hline
\end{tabular}

MLS cases were defined as patients whose main clinical signs were adenopathy in several lymph node chains, with or without hepatomegaly or splenomegaly.[13] FS cases were those with fever $>38^{\circ} \mathrm{C}$ for more than 3 days with no defined etiology and no signs of focalization.[14]

Variables Life stage (adult or child), history of known immunodeficiency, presenting syndrome suspected of herpetic etiology, PCR positivity (general to herpesviruses and to each one separately), and sample type were studied. All were qualitative nominal variables.

Samples Samples were 1-2 $\mathrm{mL}$ of serum or $5 \mathrm{~mL}$ of urine. All samples were received and stored at $-20^{\circ} \mathrm{C}$ at LSTD, after transportation to the Tropical Medicine Institute at $4{ }^{\circ} \mathrm{C}$. Two samples (serum and urine) were studied in 17 patients.

DNA extraction DNA was extracted from the urine sample as follows: $10 \mu \mathrm{L}$ of lysis solution $(50 \mathrm{mM} \mathrm{KCl}, 10 \mathrm{mM}$ Tris- $\mathrm{HCl}$ $\mathrm{pH}=9,0.1 \%$ Triton $\mathrm{X}-100)$ and $0.5 \mu \mathrm{L}$ of proteinase $\mathrm{K}(25 \mathrm{mg} /$ $\mathrm{mL}$ ) were added to $39.5 \mu \mathrm{L}$ of urine. These were incubated 45 minutes at $56{ }^{\circ} \mathrm{C}$, after which proteinase $\mathrm{K}$ was inactivated by incubation at $95{ }^{\circ} \mathrm{C}$ for 10 minutes. Serum samples were processed using $300 \mu \mathrm{L}$ of sample in a sterile vial, inactivating proteins at $95{ }^{\circ} \mathrm{C}$ for 10 minutes. Then $5 \mu \mathrm{L}$ of the lysate were used for the first PCR.[15]

Conditions for amplification PCR technique followed the protocol described by Tenorio et al.[15] Qualitative multiplex nested PCR enables genome detection of five viruses of the herpesvirus family in only one reaction tube: HSV (without differentiating type 1 or 2), VZV, CMV, HHV-6 and EBV in two amplification times or reactions. Primers amplify diverse regions of different human herpesviruses within a viral DNA polymerase fragment, as well as the pseudorabies virus (PRV), used as an internal control.

The first reaction generates a 194 base-pair (bp) product, identical for all herpesvirus. For the nested reaction, $2 \mu \mathrm{L}$ of the DNA amplified in the first reaction were used and a mixture of all typespecific primers (EUROGENTEC, USA), which allows generating different-sized products for each herpesvirus: PRV (140 bp), HSV1 or HSV2 (120 bp), VZV (98 bp), CMV (78 bp), HHV6 (66 bp) and EBV (54 bp).[15]

Afterwards, the PCR product was observed in a $4 \%$ agarose gel in TBE solution (90 mM Tris-Borate, $2 \mathrm{mM}$ EDTA pH 8.0) stained with $0.5 \mathrm{mg} / \mathrm{mL}$ ethidium bromide. Runs were ended by evaluating apparent stain migration. Amplified DNA band sizes were determined using a molecular weight standard (100 bp DNA ladder, Promega, USA) and known positive controls. The validity of each assay was confirmed by amplification of the internal control and two external controls: a negative one consisting of water instead of sample, and a positive one containing amplified DNA polymerase fragment from any herpesvirus.[15]

Statistical processing A database was created for analysis using the SPSS statistical package version 11.5. Positivity rates (percentages) were calculated for patients and samples. Odds ratios for positivity overall and for each herpesvirus were calculated by study group and clinical presentation, specifying a statistical significance cut-off $p$ value of $<0.05$ (with Yates' correction), as well as $95 \%$ confidence intervals.

Ethical aspects The study used samples and clinical information previously collected for management of FS or MLS cases with suspected herpetic etiology. The study design was approved by the Tropical Medicine Institute's ethics committee. Data management procedures ensured patient anonymity.

\section{RESULTS}

Samples studied came primarily from Havana City Province (74.6\%); among the remaining $25.4 \%$ from other provinces, $8.4 \%$ came from Villa Clara and $6.6 \%$ from Santiago de Cuba. Sex distribution was balanced, with $53.8 \%$ of samples from female patients.

Of a total 1157 samples studied, 233 were PCR positive (161 urine, 72 serum), indicating active infection by some herpesvirus in $20.1 \%$ of samples, representing $20 \%$ of patients $(228 / 1140)$. General positivity in MLS patient samples was $19.1 \%$, slightly higher in children $(20.9 \%)$ compared to adults, independent of adult HIV status (16.9\% in immunocompetent and $17.7 \%$ in HIV-positive adults) (Table 2). Samples from FS patients were more likely to be positive for some herpesvirus than were samples from MLS patients $(21.0 \%, 132 / 628$ vs $19.1 \%, 101 / 529)$ (Tables 2 and 3$)$.

CMV was the most frequently detected herpesvirus (62.2\%, 145/233) (Table 4) in samples of patients with active infections causing MLS $(60.4 \%, 61 / 101)$ and FS $(63.6 \%, 84 / 132)$ in all groups studied (Tables 2 and 3$)$, as well as in both children and adults $(69.2 \%, 81 / 117$ positive PCR in children and $55.2 \%, 64 / 116$ in adults) (Table 4). Detection of CMV genome (active infection) was significantly higher in children's samples than in those of adults (Table 5).

EBV was the second most frequently PCR-detected virus, followed by HSV, HHV6 and VZV, with similar frequencies for both syndromes (Table 4).

Table 2: Detection of herpesviruses in samples from MLS patients

\begin{tabular}{|l|r|r|r|r|}
\hline $\begin{array}{l}\text { Mononucleosis-like } \\
\text { syndrome (MLS) }\end{array}$ & $\begin{array}{c}\text { Group 1 } \\
\text { Children }\end{array}$ & $\begin{array}{c}\text { Group 1 } \\
\text { Adults }\end{array}$ & $\begin{array}{c}\text { Group 4 } \\
\text { HIV+ Adults }\end{array}$ & Total \\
\hline Samples studied & 249 & 65 & 215 & 529 \\
\hline CMV & 36 & 6 & 19 & 61 \\
\hline EBV & 8 & 1 & 8 & 17 \\
\hline HSV (either) & 2 & 2 & 5 & 9 \\
\hline HHV-6 & 3 & 1 & 3 & 7 \\
\hline VZV & 3 & 1 & 3 & 7 \\
\hline Total positive & $\mathbf{5 2}$ & 11 & 38 & 101 \\
samples & $(\mathbf{2 0 . 9 \% )}$ & $(\mathbf{1 6 . 9 \% )}$ & $(\mathbf{1 7 . 7 \% )}$ & $\mathbf{( 1 9 . 1 \% )}$ \\
\hline
\end{tabular}


Original Research

Table 3: Detection of herpesviruses in samples from FS patients

\begin{tabular}{|c|c|c|c|c|c|c|c|c|c|}
\hline \multirow{2}{*}{ Febrile syndrome (FS) } & \multicolumn{2}{|c|}{ Immunocompetent } & \multicolumn{2}{|c|}{ Transplanted } & \multicolumn{2}{|c|}{ HIV+ } & \multicolumn{2}{|c|}{ Other immunosuppressed } & \multirow{2}{*}{ Total } \\
\hline & Children & Adults & Children & Adults & Children & Adults & Children & Adults & \\
\hline Total samples & 104 & 45 & 46 & 49 & 17 & 205 & 88 & 74 & 628 \\
\hline CMV & 15 & 3 & 7 & 7 & 0 & 21 & 23 & 8 & 84 \\
\hline EBV & 0 & 1 & 3 & 1 & 0 & 7 & 6 & 3 & 21 \\
\hline HSV (either) & 0 & 2 & 2 & 2 & 0 & 3 & 3 & 3 & 15 \\
\hline Total positive samples & $16(15.3 \%)$ & $6(13.3 \%)$ & $13(28.2 \%)$ & $10(20.4 \%)$ & $0(0 \%)$ & $36(17.5 \%)$ & $36(40.9 \%)$ & $15(20.2 \%)$ & $132(21.0 \%)$ \\
\hline
\end{tabular}

Table 4: PCR positivity for herpesvirus in urine $(n=161)$ and serum $(n=72)$ samples, by virus and life stage

\begin{tabular}{l|r|r|r|}
\multirow{2}{*}{ Herpesvirus } & \multicolumn{3}{|c|}{ PCR-positive samples } \\
\cline { 2 - 4 } CMV & Children & \multicolumn{1}{|c|}{ Adults } & \multicolumn{1}{c|}{ Total } \\
\hline EBV & 81 & 64 & $145(62.2 \%)$ \\
\hline HSV (either) & 17 & 21 & $38(16.3 \%)$ \\
\hline HHV-6 & 7 & 17 & $24(10.3 \%)$ \\
\hline VZV & 7 & 8 & $15(6.4 \%)$ \\
\hline Total & 5 & 6 & $11(4.7 \%)$ \\
\hline
\end{tabular}

Generally, samples from immunocompromised FS patients were associated with detection of herpesvirus genomes: $32.5 \%$ $(49 / 151)$ of samples studied in children and $18.6 \%(61 / 328)$ in adults, compared to $15.4 \%(16 / 104)$ in immunocompetent children and $13.3 \%(6 / 45)$ in immunocompetent adults (Tables 3 and 5). Samples from immunocompromised children were more likely to be CMV-positive than those of immunocompromised adults (Table 5).

Similar rates of overall PCR positivity were found in urine and serum samples $(20.9 \%, 161 / 770$, and $18.6 \%, 72 / 387$ respectively). In positive samples, CMV was detected more often in urine $(68.9 \%, 111 / 161)$ than in serum $(47.9 \%, 34 / 72)$ (Table 5). EBV was found in $(23.6 \%, 17 / 72)$ of PCR-positive serum samples, followed by HSV $(12.5 \%, 9 / 72)$, VZV $(9.7 \%, 7 / 72)$ and HHV6 $(6.9 \%, 5 / 72)$. PCR-positive serum samples came mainly from immunocompromised FS patients $(69.4 \%, 50 / 72)$ and most PCR-positive sera were from patients with some level of immune response compromise $(45.8 \%, 33 / 72)$ or children with likely primary herpetic infection $(29.2 \%, 21 / 72)$.

Five samples were found with active herpesvirus co-infections, $80 \%$ of these in serum samples. One was from an FS HIVpositive patient with simultaneous detection of HHV6 and EBV. Another was from an immunocompetent adult with MLS in which VZV and HHV6 were detected. The remaining three were samples from children with MLS, in which HHV6 and CMV; CMV and EBV; and CMV were detected, respectively. In the last case, complicated by acute liver failure, VZV was also detected in serum.

\section{DISCUSSION}

MLS and FS may have different causes; most commonly infectious, particularly viral. Most cases are benign and selflimited, so the specific etiological agent is not sought. However, in patients with compromised immune response and in children with florid clinical presentations, it is important to determine etiology to choose appropriate treatment.[16]
Table 5: Associations with PCR positivity for herpesviruses observed in study groups

\begin{tabular}{|c|c|c|c|c|c|c|}
\hline \multirow{2}{*}{$\begin{array}{l}\text { Viral genome detected } \\
\text { (comparison groups) }\end{array}$} & \multicolumn{3}{|c|}{$\begin{array}{c}\text { Contingency Table } \\
\text { PCR Result }\end{array}$} & \multirow[t]{2}{*}{ OR } & \multirow[t]{2}{*}{$\mathrm{Cl}(95 \%)$} & \multirow{2}{*}{$\begin{array}{c}\mathbf{p} \\
\text { Value }\end{array}$} \\
\hline & & + & - & & & \\
\hline \multirow{2}{*}{$\begin{array}{l}\text { Any herpesvirus } \\
\text { in FS samples } \\
\text { (Immunodepressed vs. } \\
\text { immunocompetent) }\end{array}$} & Immunodepressed & 110 & 369 & \multirow[b]{2}{*}{1.72} & \multirow[b]{2}{*}{$1.02-2.93$} & \multirow[b]{2}{*}{0.042} \\
\hline & Immunocompetent & 22 & 127 & & & \\
\hline \multirow{2}{*}{$\begin{array}{l}\text { Any herpesvirus in FS } \\
\text { samples from children } \\
\text { (immunodepressed vs. } \\
\text { immunocompetent) }\end{array}$} & Immunodepressed & 49 & 102 & \multirow[b]{2}{*}{3.12} & \multirow[b]{2}{*}{$1.60-6.14$} & \multirow[b]{2}{*}{0.000} \\
\hline & Immunocompetent & 16 & 104 & & & \\
\hline \multirow{2}{*}{ CMV (children vs. adults) } & Children & 81 & 423 & \multirow{2}{*}{1.76} & \multirow{2}{*}{$1.22-2.54$} & \multirow{2}{*}{0.002} \\
\hline & Adults & 64 & 589 & & & \\
\hline \multirow{2}{*}{$\begin{array}{l}\text { CMV (immunodepressed } \\
\text { children vs. } \\
\text { immunodepressed adults) }\end{array}$} & $\begin{array}{l}\text { Immunodepressed } \\
\text { children }\end{array}$ & 30 & 121 & \multirow{2}{*}{2.20} & \multirow{2}{*}{$1.31-3.68$} & \multirow{2}{*}{0.002} \\
\hline & $\begin{array}{l}\text { Immunodepressed } \\
\text { adults }\end{array}$ & 55 & 488 & & & \\
\hline \multirow{2}{*}{ CMV (urine vs. serum) } & Urine & 111 & 659 & \multirow{2}{*}{1.75} & \multirow{2}{*}{$1.15-2.68$} & \multirow{2}{*}{0.008} \\
\hline & Serum & 34 & 353 & & & \\
\hline
\end{tabular}

Our study shows similar PCR-detected positivity levels to those reported in previous research using PCR to detect active herpesvirus infections in MLS patients.[17,18] Although herpesvirus etiology was suspected in cases included in this study, these agents' pathogenesis (viral replication with viremia and viral excretion) takes place during approximately the first two weeks of active infection, exact duration depending on whether it is a primary or recurrent infection and whether the patient is immunocompromised. Ten to 14 days after clinical onset, an immune response develops (humoral and cellular) resulting in virus clearance from fluids and viral latency.[2-5] At that point, direct virologic diagnostic techniques (such as PCR and viral isolation) are not useful and serological techniques become important.[2-4]

In this study, although slightly higher herpesvirus positivity was detected in samples from FS patients compared to those from MLS patients, the difference 
was not statistically significant. Most PCR-positive FS patients had prior immunosuppressive conditions (organ transplant, HIVpositivity or others). As reported internationally, these patients frequently present nonspecific FS associated with active herpesvirus infection, especially CMV but sometimes also by EBV, HSV and HHV6.[19-21]

CMV was the most frequently detected herpesvirus for all groups studied. Active CMV infection was more frequent in children than in adults. Globally, CMV is widely distributed, with high prevalences in developing countries.[22,23] Due to its tropism for endothelial cells and leucocytes, this virus is commonly found in many different cells and fluids, causing a wide range of clinical presentations.[24] Its frequency in this study was higher than classically stated, although diagnostic methods differ among the various studies.[25,26] Banko et al. affirm that PCR can be useful when specific serological tests do not lead to diagnosis, finding high rates of positivity in these cases.[17] CMV causes $8 \%$ of all MLS cases and $25-50 \%$ of MLS cases with negative humoral heterophile response in seroprevalence studies.[2] During primary infections, which generally occur during childhood, CMV produces viremia and is excreted in urine for longer periods of time than in recurrent infections. Similarly, CMV is replicated on a larger scale and for a longer time in immunocompromised patients.[2]

EBV was detected in $16.3 \%$ of PCR-positive cases, lower than the rate reported in most of the literature reviewed.[17,18] EBV has classically been associated with MLS, although it has also been associated with FS, both during primary and recurrent infections.[3] It is considered to cause $40 \%$ of all MLS cases, but most studies are based on serology rather than viral genome detection.[27] In this study, EBV was more frequently found in serum samples. During activation it can cause systemic infection and viremia, and may occasionally be excreted through the kidney. The importance and frequency of EBV are controversial and its detection in urine samples is not frequently described in the literature.[28]

Higher PCR positivity occurs in immunocompromised patients because a deficient immune response, especially cellular, is accompanied by symptomatic primary infections and more frequent viral recurrences for longer periods, as well as by higher rates of viral replication at higher levels and with longer periods of viremia and viral excretion, facilitating detection by virological techniques, as other authors have previously demonstrated.[2,11] Despite the availability of specific serological techniques for detecting antibodies to EBV, CMV and $\mathrm{HSV}$, routinely used for studying MLS, [29,30] serology is not recommended for MNS and FS diagnosis cases of deteriorated immune response, as in HIV-1 infection or after organ transplant.

The anomalous immune response in these patients may lead to errors in interpreting results.[31] Thus, the only suitable diagnostic tool in such cases is PCR.[32] Among the herpesviruses studied, CMV is the most opportunistic and the one with the worst effects, capable of further jeopardizing immune response and provoking life-threatening damage, $[3,30]$ hence its frequent and varied presentation in immunocompromised patients.
In this study, both urine and serum samples were useful for PCR herpesvirus detection. Our results are consistent with previous findings that in all herpesviruses, viremia is associated with active viral replication and clinical disease, more evident in immunocompromised persons (since immune response is not efficient), or in those with primary infections (where immune response has not yet developed).[19,21] Nevertheless, CMV's tropism for renal duct tubule epithelial cells, where active replication occurs,[2] makes urine samples best for detecting CMV excretion associated with viral replication, which can take place even in the absence of symptoms.[2,33]

Active co-infections were detected in five patients. This has been observed in other recent studies by our group and other authors, both in central nervous system infections and in transplant recipients.[7,34] Co-infections are frequently detected in immunocompromised patients.[35,36] On the other hand, in immunocompetent patients with active infection by any herpesvirus, there is a temporary immunodeficiency that predisposes to activation of another herpesvirus infection.[3] The exact implications of co-infections for the pathogenesis of herpesvirus-associated diseases are not known.[37] Multiplex $\mathrm{PCR}$, unlike conventional PCR, has the advantage of allowing simultaneous detection of several herpesviruses and thus the unique capability to identify patients with active co-infections.[38]

One limitation of our research is that no specific serological studies were performed concurrently to detect antibodies against these herpesvirus agents, so cases of longer duration in which no viremia or active virus excretion was found remained undiagnosed. As suggested by other authors,[39] these results show how challenging it is to manage herpesvirus-caused MLS or FS, dealing as we are with viruses causing lifelong latent infections with intermittent periods of reactivation.[1]

On one hand, there are serological diagnoses allowing identification of prior exposure to viral infection (by presence of IgG-specific antibodies to a determined herpesvirus), or recent primary or recurrent infection (by presence of IgM-specific antibodies to a determined herpesvirus). On the other hand, there are direct virologic diagnostic methods-PCR or viral isolation-which are more precise and enable confirmation of active viral infection, viremia, or excretion, depending on the type of sample studied and the pathogenesis of each herpesvirus.

\section{CONCLUSIONS}

The results of this study elucidate MLS and FS etiology in Cuban patients, as well as the pathogenic role of CMV, especially in immunocompromised patients. The importance is confirmed of including molecular diagnosis of the herpesvirus family in studies of MLS and FS cases of unknown etiology. Without the use of PCR, etiologic diagnosis is impossible in many of these cases. PCR enables better medical management of these syndromes, leading the way to more specific treatment in cases of immunologic deficiency that may lead to fatal outcomes and, in other cases, avoiding inappropriate antibiotic use.

We consider that complete diagnosis of herpesvirus infection associated with FS and MLS requires use of both virologic and serologic studies. -1/4 


\section{REFERENCES}

1. Pellett PE, Roizman B. The Family Herpesviridae: A Brief Introduction. In: Knipe DM, Howley PM, editors. Fields Virology. 5th ed. Philadelphia: Lippincott Williams \& Wilkins; 2007. p. 2480-97.

2. Mocarski ES, Shenk T, Pass RF. Cytomegaloviruses. In: Knipe DM, Howley PM, editors. Fields Virology. Philadelphia: Lippincott Williams \& Wilkins; 2007. p. 2703-72.

3. Rickinson AB, Kieff E. Epstein-Barr Virus. In: Knipe DM, Howley PM, editors. Fields Virology. Philadelphia: Lippincott Williams \& Wilkins; 2007. p. 2657-700.

4. Roizman B, Knipe DM, Whitley RJ. Herpes Simplex Viruses. In: Knipe DM, Howley PM, editors. Fields Virology. Philadelphia: Lippincott Williams \& Wilkins; 2007. p. 2503-601.

5. Yamanishi K, Mori Y, Pellett PE. Human Herpesviruses 6 and 7. In: Knipe DM, Howley PM, editors. Fields Virology. Philadelphia: Lippincott Williams \& Wilkins; 2007. p. 2820-45.

6. Rubin $\mathrm{RH}$. The pathogenesis and clinical management of cytomegalovirus infection in the organ transplant recipient: the end of the 'silo hypothesis'. Curr Opin Infect Dis. 2007 Aug;20(4):399-407.

7. Kouri V, Suárez C, Resik S, García S. [Herpesvirus detection in immunocompromised patients with meningoencephalitis by the polymerase chain reaction technic]. Rev Cubana Med Trop. 1998:50(3):186-90. Spanish.

8. Gaeta A, Verzaro S, Cristina LM, Mancini C, Nazzari C. Diagnosis of neurological herpesvirus infections: real time PCR in cerebral spinal fluid analysis. New Microbiol. 2009 Oct;32(4):333-40.

9. Bowers M. Herpesviruses. BETA. 1995 Dec:33-7.

10. Yoshida A. [Laboratory diagnosis of cytomegalovirus infections and disease]. Rinsho Byori. 2008 Nov;56(11):1034-42. Japanese.

11. Naumnik B, Malyszko J, Chyczewski L, Kovalchuk $\mathrm{O}$, Małyszko J, Myśliwiec M. Comparison of serology assays and polymerase chain reaction for the monitoring of active cytomegalovirus infection in renal transplant recipients. Transplant Proc. 2007 Nov;39(9):2748-50.

12. Gonzales R, Nadler PL. Common Symptoms. In: McPhee SJ, Papadakis MA, editors. Current Medical Diagnosis \& Treatment. [place unknown]: McGraw-Hill Medical; 2009. p. 21-43.

13. Llanio $R$, Lantigua $A$, Batule $M$, Matarama $M$, Arús E, Fernández A, et al. Síndromes Infecciosos. In: Síndromes. Havana: Editoral Ciencias Médicas; 2002. p. 246. Spanish.

14. Llanio R, Perdomo G. Alteraciones de la temperatura corporal. In: Propedéutica Clínica y Semiología Médica. Havana: Editoral Ciencias Médicas; 2003. p. 385-9. Spanish.

15. Tenorio A, Echevarria JE, Casas I, Echevarria $\mathrm{JM}$, Tabarés $\mathrm{E}$. Detection and typing of human herpesviruses by multiplex polymerase chain reaction. J Virol Methods. 1993 Oct;44(2-3):261-9.

16. Shandera WX, Corrales Medina VF. Viral \& Rickettsial Infections. In: McPhee SJ, Papadakis MA, editors. Current Medical Diagnosis \& Treatment. [place unknown]: McGraw-Hill Medical; 2009. p. 1205-55.

17. Banko AV, Lazarević IB, Cupić MD, Knezević AM, Stevanović GD, Krejović-Trivić SB, et al. [Correlation between results of PCR and specific serological tests in diagnosis of Epstein-Barr virus in patients with mononucleosis syndrome]. Acta Chir lugosl. 2009;56(3):71-6. Serbian.

18. Laroche $C$, Drouet EB, Brousset P, Pain C, Boibieux $A$, Biron $F$, et al. Measurement by the polymerase chain reaction of the Epstein-Barr virus load in infectious mononucleosis and AIDSrelated non-Hodgkin's lymphomas. J Med Virol. 1995 May;46(1):66-74.
19. Holzinger D, Kühn J, Ehlert $\mathrm{K}$, Groll $\mathrm{AH}$. $\mathrm{HSV}-1$ viremia as a potential cause of febrile neutropenia in an immunocompromised child. J Pediatr Hematol Oncol. 2010 Jan;32(1):19-21.

20. Yee-Guardino S, Gowans K, Yen-Lieberman B, Berk P, Kohn D, Wang FZ, et al. BetaHerpesviruses in Febrile Children with Cancer. Emerg Infect Dis. 2008 Apr;14(4):579-85.

21. Razeghi E, Hadadi A, Mansor-Kiaei M, Molavi M, Khashayar P, Pourmand G. Clinical Manifestation, Laboratory Findings, and the Response of Treatment in Kidney Transplant Recipients with CMV Infection. Transplant Proc. 2007 May;39(4):993-6.

22. Zhao P, Ma D, Xue F, Ji C, Wang S, Zhang X, et al. Seroprevalence and risk factors of human cytomegalovirus infection in the eastern Chinese population. Arch Virol. 2009;154(4):561-4.

23. Ataman S, Colak D, Günseren F, Senol Y, Colak T, Aktekin MR. [Investigation of cytomegalovirus seroepidemiology in Antalya with a population-based cross-sectional study and review of related data in Turkey]. Mikrobiyol Bul. 2007 Oct;41(4):545-55. Turkish.

24. Wang W, Yu P, Zhang P, Shi Y, Bu H, Zhang L. The infection of human primary cells and cell lines by human cytomegalovirus: new tropism and new reservoirs for HCMV. Virus Res. 2008 Feb;131(2):160-9.

25. Navalpotro D, Gimeno C, Navarro D. PCR detection of viral DNA in serum as an ancillary analysis for the diagnosis of acute mononucleosislike syndrome due to human cytomegalovirus (HCMV) in immunocompetent patients. J Clin Virol. 2006 Feb;35(2):193-6.

26. Kamar N, Mengelle C, Yahyaoui S, SandresSauné K, Durand D, Izopet J. Follow-up of 28 HCMV seropositive renal-transplant recipients: comparison of clinical, biological and virological parameters in the groups of treated versus untreated infected patients. J Clin Virol. 2005 May;33(1):35-42.

27. De Paschale M, Agrappi C, Manco MT, Mirri P Viganò EF, Clerici P. Seroepidemiology of EBV and interpretation of the «isolated VCA IgG» pattern. J Med Virol. 2009 Feb;81(2):325-31.

28. Chan KC, Leung SF, Yeung SW, Chan AT, Lo YM. Quantitative analysis of the transrenal excretion of circulating EBV DNA in nasopharyngeal carcinoma patients. Clin Cancer Res. 2008 Aug 1;14(15):4809-13.

29. Hurt C, Tammaro D. Diagnostic evaluation of mononucleosis-like illnesses. Am J Med. 2007 Oct;120(10):911.e1-8.

30. Dohno S, Maeda A, Ishiura Y, Sato T, Fujieda M, Wakiguchi $\mathrm{H}$. Diagnosis of infectious mononucleosis caused by Epstein-Barr virus in infants. Pediatr Int. 2010 Aug;52(4):536-40.

31. Gulley ML, Tang W. Laboratory assays for Epstein-Barr virus-related disease. J Mol Diagn. 2008 Jul;10(4):279-92.

32. Okay TS, Del Negro GM, Yamamoto L, Raiz Júnior R. Detection of EBV-DNA in serum samples of an immunosuppressed child during a three years follow-up: association of clinical and PCR data with active infection. Rev Inst Med Trop Sao Paulo. 2005 Mar-Apr;47(2):99-102.

33. Simmons RL, Lopez C, Balfour H Jr., Kalis J, Rattazzi LC, Najarian JS. Cytomegalovirus: Clinical Virological Correlations in Renal Transplant Recipients. Ann Surg. 1974 Oct:180(4):623-34.

34. Yamamoto T, Nakamura Y. A single tube PCR assay for simultaneous amplification of HSV1/-2, VZV, CMV, HHV-6A/-6B, and EBV DNAs in cerebrospinal fluid from patients with virusrelated neurological diseases. J Neurovirol. 2000 Oct;6(5):410-7.
35. Zawilińska B, Kosz-Vnenchak M, PiatkowskaJakubas B, Kopeć J, Daszkiewicz E, Skotnicki $A B$. [Herpesviruses mixed infections in allogeneic steam cell recipients (allo-HSCT)]. Przegl Epidemiol. 2008;62(1):39-46. Polish.

36. Razonable RR, Paya CV. The impact of human herpesvirus- 6 and -7 infection on the outcome of liver transplantation. Liver Transpl. 2002 Aug;8(8):651-8.

37. Martínez PA, Díaz R, González D, Oropesa L, González R, Pérez L, et al. The effect of highly active antiretroviral therapy on outcome of central nervous system herpesviruses infection in Cuban human immunodeficiency virus-infected individuals. J Neurovirol. 2007 Oct;13(5):446-51.

38. Tanaka T, Kogawa K, Sasa H, Nonoyama S, Furuya K, Sato K. Rapid and simultaneous detection of 6 types of human herpes virus (herpes simplex virus, varicella-zoster virus, Epstein-Barr virus, cytomegalovirus, human herpes virus $6 \mathrm{~A} / \mathrm{B}$, and human herpes virus 7) by multiplex PCR assay. Biomed Res. 2009 Oct;30(5):279-85.

39. Hess RD. Routine Epstein-Barr Virus Diagnostics from the Laboratory Perspective: Still Challenging after 35 years. J Clin Microbiol. 2004 Aug;42(8):3381-7.

\section{THE AUTHORS}

Consuelo Correa Sierra, physician with a master's degree in virology. Sexually Transmitted Disease Laboratory (STDL), Pedro Kourí Tropical Medicine Institute, Havana, Cuba.

Pedro A. Martínez Rodríguez, physician with a master's degree in virology. STDL, Pedro Kourí Tropical Medicine Institute, Havana, Cuba.

Lissette Pérez Santos, virologist with doctorate in medical sciences. STDL, Pedro Kourí Tropical Medicine Institute, Havana, Cuba.

Alina Álvarez López, industrial pharmacology technician. STDL, Pedro Kourí Tropical Medicine Institute, Havana, Cuba.

Yoan Alemán Campos, microbiologist with a master's degree in virology. STDL, Pedro Kourí Tropical Medicine Institute, Havana, Cuba.

Yudira Soto Brito, microbiologist with a master's degree in virology. STDL, Pedro Kourí Tropical Medicine Institute, Havana, Cuba.

Vivian Kourí Cardellá (Corresponding author: vkouri@ipk.sld.cu), physician specializing in microbiology with a doctorate in medical sciences. STDL, Pedro Kourí Tropical Medicine Institute, Havana, Cuba.

Submitted: August 26, 2010

Approved for publication: August 25, 2011 Disclosures: None 